\title{
Correlation between the tumoral expression of $\beta 3$-integrin and outcome in cervical cancer patients who had undergone
} radiotherapy

\author{
G Gruber', J Hess', C Stiefel', DM Aebersold', Y Zimmer', RH Greiner', U Studer', HJ Altermatt ${ }^{2}$, \\ R Hlushchuk ${ }^{3}$ and V Djonov*,3 \\ 'Department of Radiation Oncology, University of Bern, Switzerland; ${ }^{2}$ Pathology Laenggasse, Bern, Switzerland; ${ }^{3}$ Institute of Anatomy, University of Bern, \\ Baltzerstrasse 2, $\mathrm{CH}-3000$ Bern 9, Switzerland
}

\begin{abstract}
Integrins are cell-surface receptors, which mediate cell-to-cell and cell-to-extracellular matrix adhesion. Besides playing an important role in tumour angiogenesis, $\beta 3$-integrin is also expressed in several types of epithelial cancer cells. It was the purpose of the present study to evaluate the prognostic value of $\beta 3$-integrin expression in patients with cervical cancer. Biopsies were taken from 82 patients with squamous cell or adenocarcinomas of the uterine cervix who had undergone external-beam radiotherapy with or without brachytherapy. These tissue samples were analysed immunohistochemically for the expression of $\beta 3$-integrin. The impact of immunoreactivity for $\beta 3$-integrin on survival end points was assessed by univariate and multivariate analyses, and its correlation with clinicopathological characteristics evaluated by crosstabulations. $\beta 3$-integrin was expressed in $61 \%$ (50 of 82) of the patients. KaplanMeier curves revealed local progression-free survival, distant metastasis-free survival and cause-specific survival to be significantly shorter ( $P$-values according to the log-rank test: 0.002, 0.04 and 0.01 , respectively) in patients with $\beta 3$-integrin expression. The prognostic impact of this parameter was even higher than for other well-known prognostic parameters and remained statistically significant in the multivariate analyses. $\beta 3$-integrin, which is expressed in the majority of patients with advanced cervical cancer, has a significant prognostic impact on outcome according to univariate and multivariate analyses.

British Journal of Cancer (2005) 92, 4 I-46. doi: I0.1038/sj.bjc.6602278 www.bjcancer.com
\end{abstract}

Published online 14 December 2004

(c) 2005 Cancer Research UK

Keywords: $\beta 3$-integrin expression; cervical cancer; radical radiotherapy

Tumour cells are heavily influenced by their microenvironment. They derive important information not only from soluble factors, such as hormones, cytokines and growth factors, but also via direct interactions with neighbouring cells and extracellular matrix molecules.

The integrins are a family of transmembrane cell-surface receptors, which participate in cell-to-cell and cell-to-extracellular matrix interactions. They consist of $\alpha$ - and $\beta$-subunits. The cytoplasmic tails of the $\beta$-subunit contain two highly conserved motifs (NPXY and NXXY), which play a major role in the regulation of integrin-mediated functions (Dedhar and Hannigan, 1996). At least 20 different signalling proteins can associate with activated integrin receptors (Miyamoto et al, 1995). These cooperative interactions set in train signalling cascades, which are involved in cell differentiation, adhesion, migration, invasion, proliferation, angiogenesis and survival (for reviews, see Varner and Cheresh, 1996; Dedhar, 1999; Brakebusch et al, 2002). And, there is an increasing body of evidence indicating that integrins mediate the development of metastases in certain organs (Pecheur

*Correspondence: Dr V Djonov; E-mail: valentin.djonov@ana.unibe.ch Received 9 August 2004; revised 30 September 2004; accepted 21 October 2004; published online 14 December 2004 et al, 2002). Several of these signalling cascades involve ras or phosphatidyl inositol 3-kinase, and have been demonstrated to prevent apoptosis (for review, see Shain et al, 2000). Some of the aforementioned biological events are at least partially invoked by intercommunication between growth-factor receptors and integrins (Miyamoto et al, 1996; Eliceiri and Cheresh, 2001). There is a growing body of evidence indicating that integrins are involved in drug resistance (for a review, see Shain et al, 2000).

$\alpha v \beta 3$ is one of the most actively investigated members of the integrin receptor family. It is overexpressed in blood vessels, and together with the other known $\beta$-3 integrin, $\alpha I b \beta 3$, is synthesised by malignant epithelial cells. Comparative ELISA and immunoprecipitation have revealed $\alpha v \beta 3$ to be expressed at much higher levels in human malignant cervical tumours than in nonmalignant cervical tissue (Chattopadhyay and Chatterjee, 2001). The clinical significance has been prospectively analysed in 111 patients with melanomas of intermediate thickness. The analysis revealed the expression of $\beta 3$-integrins to be associated with a higher risk of death (Hieken et al, 1996, 1999).

In the present study, we wished to ascertain whether the expression of $\beta 3$-integrins could serve as a prognostic marker for survival in cervical cancers that had undergone radiotherapy. We also wished to determine whether the expression of $\beta 3$-integrins is linked with that of $\mathrm{p} 53$, since the administration of $\alpha v \beta 3$ 
antagonists during angiogenesis is known to induce apoptosis, to selectively activate the synthesis of $\mathrm{p} 53$ by endothelial cells and to increase the expression of the p53-inducible cell-cycle inhibitor, p $21^{\mathrm{WAF} 1 / \mathrm{CIP} 1}$ (Stromblad et al, 1996).

\section{PATIENTS AND METHODS}

In all, 91 patients who had undergone radiotherapy with a curative intent for squamous cell or adenocarcinomas of the cervix between 1990 and 1998 were eligible for this study. Individuals who had received surgical treatment for the primary tumour or the regional lymph nodes were not included. Biopsies from paraffin-embedded tissue samples were obtained with the approval of the Regional Board of the Medical Ethics Commission and with the informed written consent of the patients. In nine cases, no biopsy material was available, and these patients were excluded. Hence, 82 individuals qualified for inclusion in this study. In total, 73 of these patients had advanced FIGO stages (IIb-IVa) and nine had FIGO stages Ib-IIa. The latter nine patients were subjected to radiotherapy owing to comorbidity, which rendered their condition inoperable.

The clinical characteristics of the patient cohort are summarised in Table 1. Tumour staging was ascertained by clinical examination under anaesthesia, by chest X-radiography and by computer tomography (CT) of the pelvis, which was replaced or supplemented by MRI in several patients. Suspicious radiological findings respecting the size $(>1 \mathrm{~cm})$ and configuration of regional lymph nodes were not routinely substantiated by a histopathological analysis. However, borderline cases did undergo histopathological evaluation, and in seven of these positive lymph nodes were revealed. Prior to radiotherapy, all patients underwent two- or three-dimensional CT-based planning, simulator and portal-vision imaging devices being used as controls. External-beam radiotherapy (EBRT) was delivered via a 6- or 15-MV linear accelerator, a median total dose of $56 \mathrm{~Gy}$ (range: $31-67$ ) being administered. A four-field box technique was used to deliver daily fractions of 1.8 or $2 \mathrm{~Gy}$ five times per week.

If the tumour regressed sufficiently after EBRT, then high-doserate brachytherapy (BT) with 192-Ir was administered. A median 192-Ir dose of $17 \mathrm{~Gy}$, delivered in a median of four fractions, was given to point A. In 21 of the 82 patients, BT could not be instigated owing to the persistence of the tumoral mass and/or the destruction of the cervix, which rendered intracavitary treatment impossible. In these cases, a higher dose of EBRT was applied. The median total dose delivered to point A was $69 \mathrm{~Gy}$. A total of 27 patients (33\%) underwent concomitant cisplatin-based chemotherapy.

Following the course of radiotherapy, patients underwent a clinical examination and pelvic MRI or CT to define the response to treatment. The follow-up included clinical examinations in our department and/or by a gynaecologist. The mean follow-up time was 41 months (range: 3-131 months).

\section{Immunohistochemistry}

33-integrins: Sections ( $3 \mu \mathrm{m}$ thick) of paraffin-embedded biopsy material were transferred to gelatinised microslides and air-dried overnight at $37^{\circ} \mathrm{C}$. They were then dewaxed in xylene (three changes), rehydrated in ethanol and rinsed twice in Tris-buffered saline (TBS: $50 \mathrm{~mm}$ Tris/ $\mathrm{HCl}$ ( $\mathrm{pH} 7.4$ ) containing $100 \mathrm{~mm}$ sodium chloride). Endogenous peroxidase activity was suppressed by treatment with $0.3 \%$ hydrogen peroxide (in TBS) for $10 \mathrm{~min}$. Sections were then treated in a microwave oven $(180 \mathrm{~W})$ for $15 \mathrm{~min}$ and treated with $1 \%$ casein ((Sigma 8654) in TBS) for $10 \mathrm{~min}$ to block unspecific binding. They were then incubated with the first antibody: mouse monoclonal anti- $\beta 3$-integrins ((MAB2008; Chemicon International, Temecula, CA, USA) diluted $1: 50$ in TBS) for $15 \mathrm{~h}$ at $4{ }^{\circ} \mathrm{C}$. Subsequently, the sections were exposed to an affinitypurified biotinylated second antibody ((anti-mouse EO 433; Dako,
Table I Bivariate correlations (Fisher's exact test) between $\beta 3$-integrin expression and patient-, tumour- and therapy-related parameters

\begin{tabular}{|c|c|c|c|c|}
\hline \multirow[b]{2}{*}{ Parameter } & \multicolumn{4}{|c|}{$\beta 3$ expression } \\
\hline & Total (\%) & Negative (\%) & Positive $^{\mathbf{a}}(\%)$ & $P$-value \\
\hline Total & $82(100)$ & $32(39)$ & $50(6 \mid)$ & \\
\hline \multicolumn{5}{|l|}{ Median age (yrs) } \\
\hline$<63$ & $41(50)$ & $13(32)$ & $28(68)$ & \\
\hline$\geqslant 63$ & $41(50)$ & $19(46)$ & $22(54)$ & 0.26 \\
\hline \multicolumn{5}{|l|}{ FIGO stage } \\
\hline$|/| \mid$ & $42(5 \mathrm{I})$ & $18(43)$ & $24(57)$ & \\
\hline III/IV & $40(49)$ & $14(35)$ & $26(65)$ & 0.50 \\
\hline \multicolumn{5}{|l|}{ Differentiation $^{\text {b }}$} \\
\hline Grade I & $3(4)$ & & & \\
\hline Grade 2 & $40(55)$ & $16(40)$ & $24(60)$ & \\
\hline Grade 3 & $30(4 I)$ & $12(40)$ & $18(60)$ & 1.00 \\
\hline \multicolumn{5}{|c|}{ Lymph-node metastasis } \\
\hline Yes & $32(39)$ & $9(28)$ & $23(72)$ & \\
\hline No & $50(61)$ & $23(46)$ & $27(54)$ & 0.16 \\
\hline \multicolumn{5}{|l|}{ Histology } \\
\hline Adeno/-squamous & $15(18)$ & $7(47)$ & $8(53)$ & \\
\hline Squamous & $67(82)$ & $25(37)$ & $42(63)$ & 0.57 \\
\hline \multicolumn{5}{|l|}{ P53 expression ${ }^{b}$} \\
\hline Negative & $54(67)$ & $21(39)$ & $33(6 I)$ & \\
\hline Positive & $26(33)$ & $10(38)$ & $16(62)$ & 1.00 \\
\hline \multicolumn{5}{|l|}{ Haemoglobin ${ }^{\mathrm{b}}$} \\
\hline <Median & $40(49)$ & $17(42)$ & $23(58)$ & \\
\hline$>$ Median & $4 \mid(5 I)$ & $14(34)$ & $27(66)$ & 0.50 \\
\hline \multicolumn{5}{|c|}{ Median total dose (Gy) } \\
\hline$\leqslant 69$ & $42(5 \mathrm{I})$ & $16(38)$ & $26(62)$ & \\
\hline$>69$ & $40(49)$ & $16(40)$ & $24(60)$ & 1.00 \\
\hline \multicolumn{5}{|l|}{ Radiotherapy } \\
\hline BT & I (I) & & & \\
\hline $\mathrm{EBRT}+\mathrm{BT}$ & $60(73)$ & $25(42)$ & $35(58)$ & \\
\hline EBRT & $21(26)$ & $6(29)$ & $15(7 \mid)$ & 0.43 \\
\hline \multicolumn{5}{|l|}{ Chemotherapy } \\
\hline Yes & $27(33)$ & $7(26)$ & $20(74)$ & \\
\hline No & $55(67)$ & $25(45)$ & $30(55)$ & 0.10 \\
\hline
\end{tabular}

$\mathrm{BT}=$ brachytherapy; EBRT = external-beam radiotherapy. ${ }^{\mathrm{a}}$ Combined group of 'weak' and 'strong' $\beta 3$ expression. 'Parameter was not available for all patients.

Glostrup, Denmark) diluted 1:200 in TBS) for $45 \mathrm{~min}$ at ambient temperature, washed three times in TBS and then treated with the avidin-biotin-horseradish peroxidase complex (P355, Dako, Glostrup, Denmark) for a similar period at the same temperature. The reaction product was visualised by exposing sections to 3amino-9-ethylcarbazole or to 3,3-diaminobenzidine (Sigma Chemicals Company, St Louis, MI, USA). They were then mounted in Aquatex (Merck, Darmstadt, Germany). Negative controls were prepared using nonspecific mouse sera.

Initially, it was planned to evaluate the expression of $\beta 3$ integrins within tumoral endothelial cells as well as within the epithelial ones. However, the endothelial cells seldom expressed $\beta 3$-integrins, probably because the biopsies were usually small and therefore lacked activated capillaries characteristic for vascular 'hot spots' (Gasparini et al, 1998). Immunoreactivity for $\beta 3$ integrins within tumoral epithelial cells was graded semiquantitatively as follows: - , undetected or negligible $(<1 \%$ of the tumoral cells registering positive); + , weak $(1-10 \%$ of the tumoral cells registering positive); and ++ , strong ( $>10 \%$ of the tumour cells 
registering positive). When more than one biopsy per patient was available, the highest score was selected for further evaluation. The assessment was performed at a final magnification of $\times 200$ in a blinded manner and independently by two investigators (JH, VD). Conflicting scores were resolved at a discussion microscope.

p53: Sections ( $3 \mu \mathrm{m}$ thick) of paraffin-embedded biopsy material were treated as described for $\beta 3$-integrins up to the end of the incubation with $0.3 \%$ hydrogen peroxide. They were then bathed in $0.01 \mathrm{M}$ sodium citrate ( $\mathrm{pH} 6.0$ ), heated in a microwave oven $(180 \mathrm{~W}$ ) for $15 \mathrm{~min}$ and exposed to $1 \%$ casein (in TBS) for $10 \mathrm{~min}$. Sections were then incubated with the first antibody: mouse antip53 ((DO-7. M 7001; DAKO, Glostrup, Denmark) diluted 1:200 in TBS) for $15 \mathrm{~h}$ at $4{ }^{\circ} \mathrm{C}$. Exposure to the second antibody and subsequent treatment accorded with the descriptions already given for $\beta 3$-integrins. Negative controls were similarly prepared using nonspecific mouse sera. Sections were counterstained with haematoxylin. If more than $10 \%$ of the tumour cells exhibited intense nuclear staining, p53 was considered to have been overexpressed. When more than one biopsy per patient was available, the highest score was selected for further evaluation. Sections were assessed microscopically as described for $\beta 3$ integrins.

\section{Statistics}

The bivariate analysis involving the expression of $\beta 3$-integrins and clinicopathological covariables was conducted using Fisher's exact test, the two-sided significance level being set at $5 \%$.

For the survival analysis, three end points were used: local progression-free survival (LPFS), distant metastasis-free survival (DMFS) and cause-specific survival (CSS). Local progression during or after therapy was the determining event for LPFS, and death from the tumour (not from noncancer-related cause) for CSS. LPFS, DMFS and CSS were investigated by univariate and multivariate analyses (using the log-rank test and Cox's model, respectively). The qualifying criterion for inclusion in Cox's regression analysis was a $P$-value $\leqslant 0.1$ in the univariate analysis. A backward elimination procedure was then performed to eliminate nonsignificant parameters $(P \geqslant 0.1)$. Survival curves were plotted according to the Kaplan-Meier method, the log-rank test being used to determine significant differences between these. Statistical analyses were performed using the SPSS package (Version 11.0; SPSS Inc., Chicago, IL, USA).

\section{RESULTS}

\section{Expression of $\beta 3$-integrins}

In 32 patients (39\%), $\beta 3$-integrins were either not detected or expressed at negligible levels. In the cases that manifested clear evidence of immunoreactivity $(n=50 ; 61 \%), 31(38 \%)$ exhibited 'weak' $(+)$ and $19(23 \%)$ 'strong' $(++)$ staining (Figure 1). Bivariate correlations revealed no significant association between the expression of $\beta 3$-integrins and any clinicopathological parameter, including p53 expression. However, biopsies derived from patients with clinically positive lymph nodes and from those who had undergone chemotherapy were more prone to register positive for $\beta 3$-integrins. The crosstabulations are summarised in Table 1.

\section{Univariate survival analysis}

The Kaplan-Meier survival curves (Figure 2) revealed significantly worse LPFS $(P=0.007)$ and CSS $(P=0.038)$, and a tendency for impaired DMFS $(P=0.09)$ in patients expressing $\beta 3$-integrins. Those with 'weak' or 'strong' $\beta 3$-integrin expression had a similar outcome and were combined for further statistical analyses. These disclosed patients with $\beta 3$-integrins positivity to fare significantly worse with respect to all end points (LPFS: $P=0.002$; DMFS: $P=0.036$; and CSS: $P=0.011$ )

For LPFS, lymph-node status $(P=0.009)$, the pretreatment level of haemoglobin $(P=0.03)$ and the implementation of BT
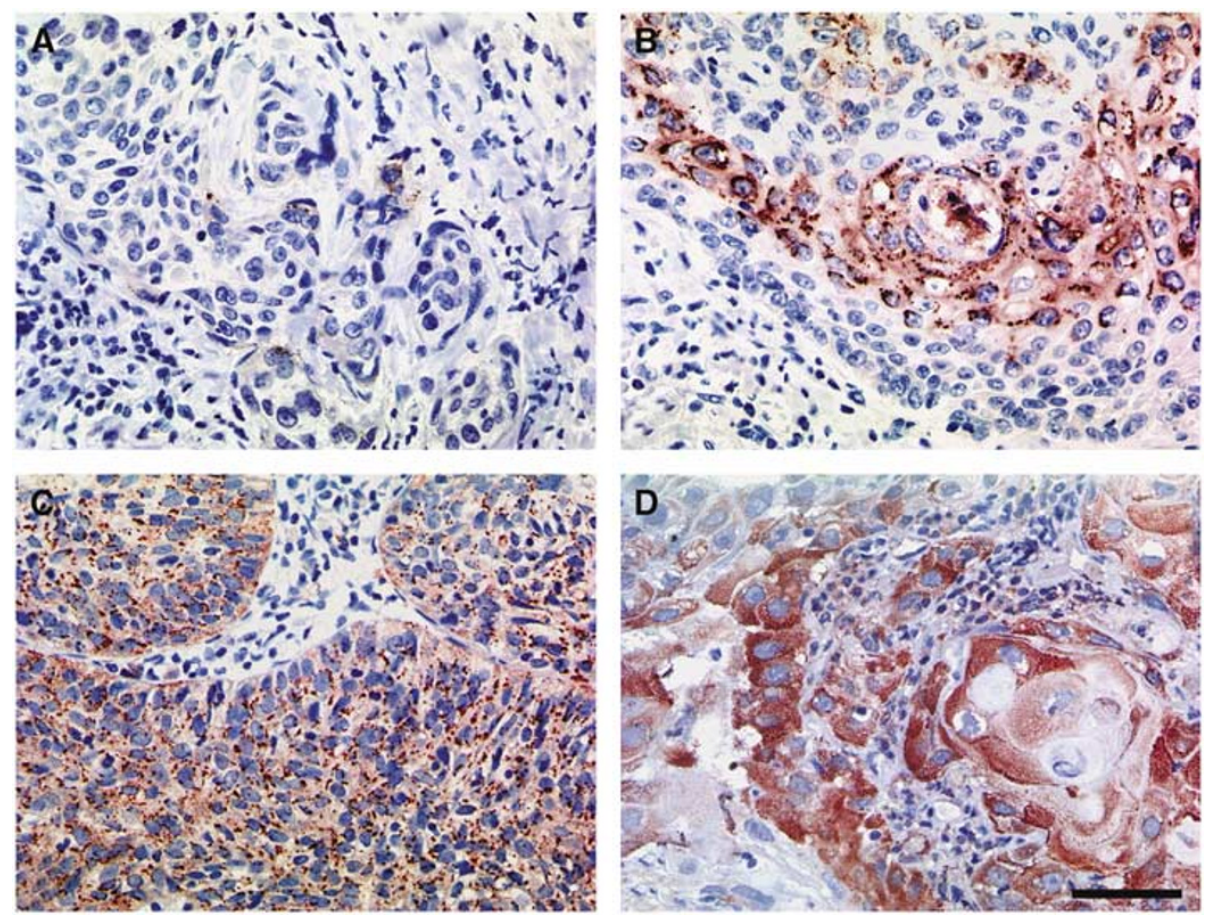

Figure I Graded semiquantitatively immunoreactivity for $\beta$-integrins (brown colouration) within tumoral epithelial cells: undetected or negligible (A), weak (B) and strong (C and D). Bar $50 \mu \mathrm{m}$ - see (D). 

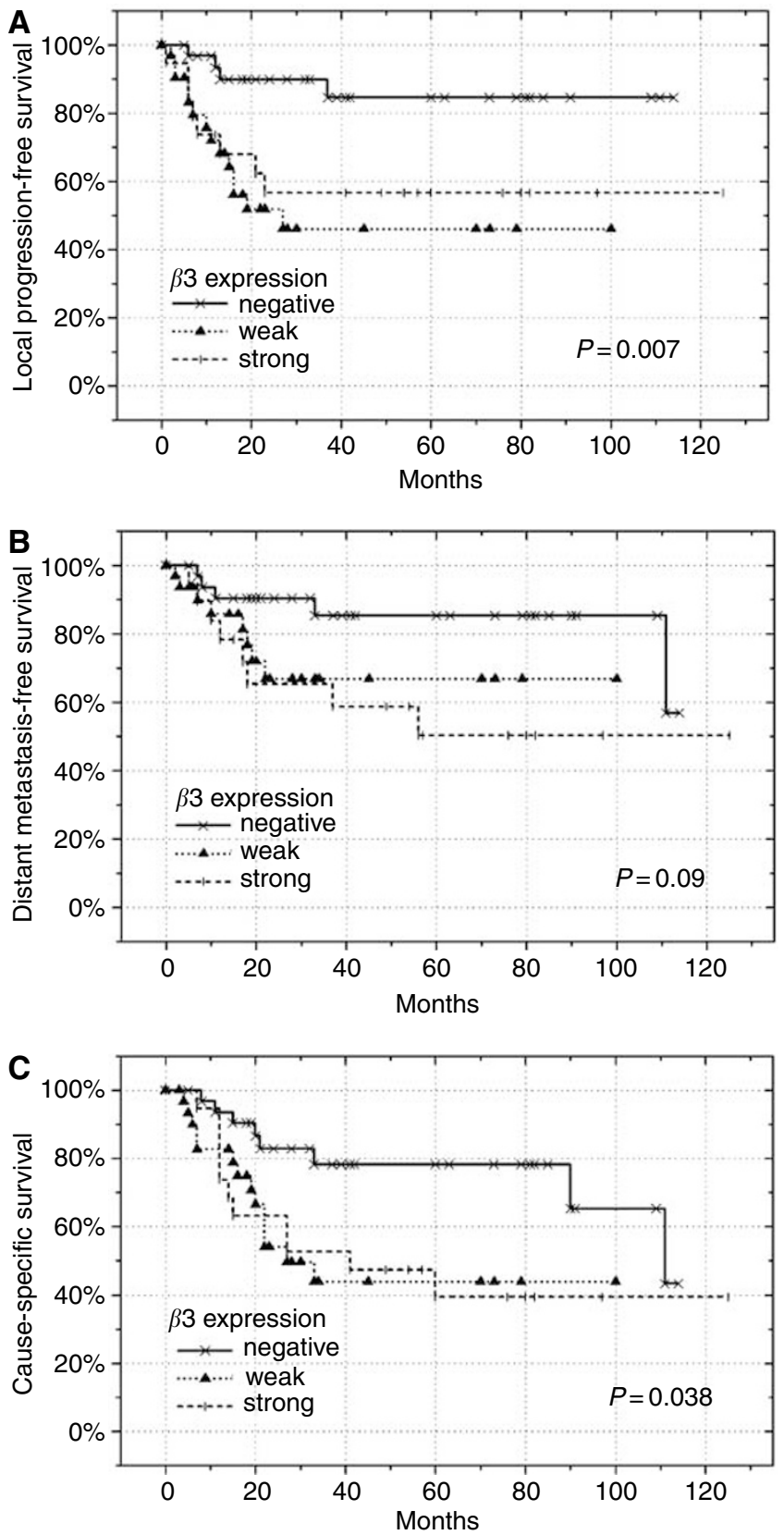

Figure 2 Local progression-free survival (A), DMFS (B) and CSS (C), expressed as a function of 'negative', 'weak' or 'strong' immunoreactivity for $\beta 3$-integrins in our cohort of 82 patients with cervical cancer. P-values were determined according to the log-rank test.

$(P=0.009)$ were also significant. FIGO stage and the histological tumour type had a borderline impact $(P=0.09$ and 0.07 , respectively). For DMFS and CSS, lymph-node status and histological tumour type were significant. The results of the univariate survival analysis are summarised in Table 2.

\section{Multivariate survival analysis}

Cox's regression analysis confirmed $\beta 3$-integrins positivity to have an independent and significant bearing on outcome (LPFS: $\mathrm{RR}=6.81, P=0.001$; DMFS: $\mathrm{RR}=3.99, P=0.016$; $\mathrm{CSS}: \mathrm{RR}=4.36$, $P=0.002)$. The histological subtype likewise had an impact on all end-points (LPFS: $\mathrm{RR}=3.47, P=0.01$; $\mathrm{DMFS}$ : $\mathrm{RR}=4.25, P=0.007$; CSS: $R R=4.52, P=0.001)$. The pretreatment level of haemoglobin
Table 2 Estimates of LPFS, DMFS and CSS 5 years after treatment, determined according to the Kaplan-Meier method* and the univariate analyses (log-rank test**) for various clinicopathological characteristics in our cohort of 82 patients with cervical cancer

\begin{tabular}{|c|c|c|c|c|c|c|}
\hline \multirow[b]{2}{*}{ Parameter } & \multicolumn{2}{|c|}{5 yrs - LPFS* } & \multicolumn{2}{|c|}{5 yrs - DMFS* } & \multicolumn{2}{|c|}{5 yrs - CSS* } \\
\hline & $\%$ & $P$-value** & $\%$ & $P$-value** & $\%$ & $P$-value** \\
\hline Age & & 0.53 & & 0.60 & & 0.80 \\
\hline $\begin{array}{l}\text { < Median } \\
>\text { Median }\end{array}$ & $\begin{array}{l}60 \pm 8 \\
69 \pm 8\end{array}$ & & $\begin{array}{l}65 \pm 9 \\
74 \pm 8\end{array}$ & & $\begin{array}{l}51 \pm 9 \\
62 \pm 8\end{array}$ & \\
\hline FIGO stage & & $0.09^{\mathrm{a}}$ & & 0.80 & & 0.25 \\
\hline I/II & $\begin{array}{l}72 \pm 8 \\
54 \pm 9\end{array}$ & & $\begin{array}{l}72 \pm 8 \\
64 \pm 10\end{array}$ & & $\begin{array}{l}64 \pm 8 \\
46 \pm 9\end{array}$ & \\
\hline Histology & & $0.07^{\mathrm{a}}$ & & $0.012^{\mathrm{a}}$ & & $0.016^{\mathrm{a}}$ \\
\hline $\begin{array}{l}\text { Adeno/-squamous } \\
\text { Squamous }\end{array}$ & $\begin{array}{l}48 \pm 14 \\
68 \pm 6\end{array}$ & & $\begin{array}{l}41 \pm 15 \\
75 \pm 6\end{array}$ & & $\begin{array}{l}34 \pm 13 \\
60 \pm 7\end{array}$ & \\
\hline Differentiation & & 0.14 & & 0.62 & & 0.22 \\
\hline $\begin{array}{l}\text { Grade } 2 \\
\text { Grade } 3\end{array}$ & $\begin{array}{l}56 \pm 9 \\
78 \pm 8\end{array}$ & & $\begin{array}{l}64 \pm 10 \\
74 \pm 9\end{array}$ & & $\begin{array}{l}48 \pm 9 \\
65 \pm 9\end{array}$ & \\
\hline Nodal status & & $0.009^{\mathrm{a}}$ & & $0.004^{a}$ & & $0.002^{\mathrm{a}}$ \\
\hline $\begin{array}{l}\text { Negative } \\
\text { Positive }\end{array}$ & $\begin{array}{l}76 \pm 6 \\
43 \pm 10\end{array}$ & & $\begin{array}{l}82 \pm 7 \\
47 \pm 11\end{array}$ & & $\begin{array}{l}69 \pm 7 \\
32 \pm 10\end{array}$ & \\
\hline Haemoglobin & & $0.03^{\mathrm{a}}$ & & 0.89 & & $0.09^{\mathrm{a}}$ \\
\hline $\begin{array}{l}\text { < Median } \\
\text { > Median }\end{array}$ & $\begin{array}{l}51 \pm 10 \\
73 \pm 7\end{array}$ & & $\begin{array}{l}66 \pm 11 \\
69 \pm 8\end{array}$ & & $\begin{array}{l}45 \pm 10 \\
61 \pm 8\end{array}$ & \\
\hline Chemotherapy & & 0.95 & & 0.56 & & 0.88 \\
\hline $\begin{array}{l}\text { Yes } \\
\text { No }\end{array}$ & $\begin{array}{l}65 \pm 10 \\
64 \pm 7\end{array}$ & & $\begin{array}{l}65 \pm 10 \\
73 \pm 7\end{array}$ & & $\begin{array}{l}55 \pm 10 \\
56 \pm 8\end{array}$ & \\
\hline Brachytherapy & & $0.009^{\mathrm{a}}$ & & 0.98 & & 0.16 \\
\hline $\begin{array}{l}\text { Yes } \\
\text { No }\end{array}$ & $\begin{array}{l}69 \pm 6 \\
45 \pm 13\end{array}$ & & $\begin{array}{l}68 \pm 7 \\
72 \pm 13\end{array}$ & & $\begin{array}{l}58 \pm 7 \\
45 \pm 13\end{array}$ & \\
\hline Total dose & & 0.47 & & 0.81 & & 0.43 \\
\hline $\begin{array}{l}\text { < Median } \\
\text { > Median }\end{array}$ & $\begin{array}{l}61 \pm 9 \\
67 \pm 8\end{array}$ & & $\begin{array}{l}71 \pm 9 \\
67 \pm 8\end{array}$ & & $\begin{array}{l}55 \pm 9 \\
57 \pm 9\end{array}$ & \\
\hline P53 expression & & 0.20 & & 0.75 & & 0.20 \\
\hline $\begin{array}{l}\text { Negative } \\
\text { Positive }\end{array}$ & $\begin{array}{l}71 \pm 6 \\
51 \pm 12\end{array}$ & & $\begin{array}{l}69 \pm 7 \\
71 \pm 10\end{array}$ & & $\begin{array}{l}58 \pm 8 \\
51 \pm 11\end{array}$ & \\
\hline$\beta 3$ expression & & 0.007 & & 0.09 & & 0.038 \\
\hline $\begin{array}{l}\text { Negative } \\
\text { Weak positive }\end{array}$ & $\begin{array}{l}85 \pm 7 \\
46+10\end{array}$ & & $\begin{array}{l}85 \pm 7 \\
67+10\end{array}$ & & $\begin{array}{l}78 \pm 8 \\
44+10\end{array}$ & \\
\hline Strong positive & $57 \pm 12$ & & $50 \pm 13$ & & $39 \pm 12$ & \\
\hline$\beta 3$ expression & & $0.002^{\mathrm{a}}$ & & $0.036^{\mathrm{a}}$ & & $0.011^{\mathrm{a}}$ \\
\hline $\begin{array}{l}\text { Negative } \\
\text { Positive }\end{array}$ & $\begin{array}{l}85 \pm 7 \\
51 \pm 8\end{array}$ & & $\begin{array}{l}85 \pm 7 \\
57 \pm 9\end{array}$ & & $\begin{array}{l}78 \pm 8 \\
41 \pm 8\end{array}$ & \\
\hline
\end{tabular}

LPFS = local progression-free survival; DMFS = distant metastasis-free survival;

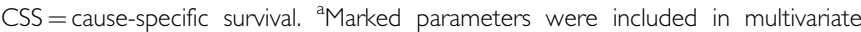
analysis.

was significant for LPFS $(\mathrm{RR}=0.31, P=0.005)$ and CSS $(\mathrm{RR}=0.45, P=0.033)$. Nodal status was of borderline significance for DMFS $(P=0.06)$ and CSS $(P=0.08)$. For LPFS, neither nodal status nor FIGO stage was important. These findings are summarised in Table 3.

\section{DISCUSSION}

Within the large integrin family, only two of the known $\alpha$-subunits, $\alpha I b$ and $\alpha v$, can dimerise with $\beta 3$, thereby yielding $\alpha I I b \beta 3$ and 
Table 3 Multivariate analysis for LPFS, DMFS and CSS according to Cox's regression model in our cohort of 82 patients with cervical cancer

\begin{tabular}{|c|c|c|c|}
\hline & $\begin{array}{c}\text { LPFS } \\
\text { P-value } \\
\text { RR }(95 \% \mathrm{CI})\end{array}$ & $\begin{array}{c}\text { DMFS } \\
\text { P-value } \\
\text { RR }(95 \% \mathrm{CI})\end{array}$ & $\begin{array}{c}\text { CSS } \\
\text { P-value } \\
\text { RR }(95 \% \mathrm{CI})\end{array}$ \\
\hline $\begin{array}{l}\text { FIGO stage } \\
\text { III/IV vs I/II }\end{array}$ & $\begin{array}{c}0.39 \\
1.47(0.61-3.57)\end{array}$ & - & - \\
\hline $\begin{array}{l}\text { Histology } \\
\quad \text { Adeno/- } \\
\text { squamous vs } \\
\text { squamous }\end{array}$ & $\begin{array}{c}0.01 \\
3.47(1.31-9.17)\end{array}$ & $\begin{array}{c}0.007 \\
4.25(1.50-12.04)\end{array}$ & $\begin{array}{c}0.001 \\
4.52(1.83-11.18)\end{array}$ \\
\hline $\begin{array}{l}\text { Nodal status } \\
\text { Positive vs } \\
\text { negative }\end{array}$ & $\begin{array}{c}0.49 \\
1.34(0.59-3.03)\end{array}$ & $\begin{array}{c}0.06 \\
2.32(0.94-5.76)\end{array}$ & $\begin{array}{c}0.08 \\
1.87(0.92-3.8 \mid)\end{array}$ \\
\hline $\begin{array}{l}\text { Haemoglobin } \\
>\text { Median vs } \\
<\text { median }\end{array}$ & $\begin{array}{c}0.005 \\
0.3 \mid(0.14-0.7 \mid)\end{array}$ & & $\begin{array}{c}0.033 \\
0.45(0.22-0.94)\end{array}$ \\
\hline $\begin{array}{c}\text { Brachytherapy } \\
\text { Yes vs no }\end{array}$ & $\begin{array}{c}0.09 \\
0.49(0.21-1.12)\end{array}$ & - & - \\
\hline $\begin{array}{l}\beta 3 \text { expression } \\
\text { Positive vs } \\
\text { negative }\end{array}$ & $\begin{array}{c}0.001 \\
6.81(2.21-21.00)\end{array}$ & $\begin{array}{c}0.016 \\
3.99(1.29-12.35)\end{array}$ & $\begin{array}{c}0.002 \\
4.36(1.73-11.00)\end{array}$ \\
\hline
\end{tabular}

LPFS = local progression-free survival; DMFS = distant metastasis-free survival; $\mathrm{CSS}=$ cause-specific survival; $\mathrm{RR}=$ risk ratio; $\mathrm{Cl}=$ confidence interval.

$\alpha v \beta 3$. Hitherto, $\alpha I b \beta 3$ was believed to be expressed only within cells of the megakaryocyte lineage (Hynes, 1992). However, recent findings have revealed this integrin to be synthesised by a variety of tumour cells at different histological sites, such as blood, the lung, liver, kidney, colon, bladder, breast, prostate and cervix (Chen et al, 1997).

The integrin $\alpha v \beta 3$, also known as the vitronectin receptor, has been implicated in the pathophysiology of malignant tumours. It plays an important role in angiogenesis, particularly via its expression in 'activated' endothelial cells (Brooks et al, 1994). However, the exact mechanisms underlying pro- and antiangiogenic signalling remain obscure (for a review, see Hodivala-Dilke et al, 2003). More recently, tumour cells have also been recognised to synthesise $\alpha v \beta 3$ (Chen et al, 1997). A possible link between its expression therein and tumour progression and/or invasiveness has been suggested for melanomas, glioblastomas and cancers of the breast, stomach and cervix (Albelda et al, 1990; Pignatelli et al, 1992; Gingras et al, 1995; Kawahara et al, 1995; Chattopadhyay and Chatterjee, 2001).

In a few studies, a significant association has been demonstrated to exist between patient survival and the expression of $\alpha v \beta 3$ by vascular 'hot spots', which served as a marker for angiogenesis (Gasparini et al, 1998; Vonlaufen et al, 2001). No data respecting a possible link between $\alpha I I b \beta 3$ expression and outcome have been forthcoming. In human melanomas, both the $\beta 3$-integrins are likely to be involved in tumour progression (Trikha et al, 2002). In a study involving 111 patients with primary malignant melanomas, $71(64 \%)$ were shown to express $\beta 3$-integrins (Hieken et al, 1999), and these individuals were more likely to develop lung metastasis and to die of their disease $(45 \%$ (32 of 71 patients)) than were those with $\beta 3$-integrin-negative tumours $(8 \%$ (three of 40 patients)), a finding that was highly significant $(P<0.0001)$.

We here report for the first time that likewise in patients (most of them) with advanced stages of cervical cancer, the expression of $\beta 3$-integrins is associated with an impaired outcome, irrespective of the level of immunoreactivity. Indeed, the significance of this factor was higher than for other prognostic parameters. Lymphnode metastasis, a very potent parameter in the univariate analysis, failed to attain significance for LPFS in Cox's regression model, which is contrary to previous findings of our group (Burri et al, 2003). There exist some differences in patient number and in the follow-up time, but these factors alone cannot account for the present results. The inclusion of $\beta 3$-integrins as a new parameter in the multivariate analysis most likely diminished the importance of lymph-node status. In the present investigation, overall survival was replaced by CSS, since several patients had a high comorbidity.

Integrin positivity was related to both local and distant failure and might be more an indicator for a bad prognosis in general than a predictor for radiation response. Although a direct action of specific integrin inhibitors on tumour growth is foreseeable, a combined approach, involving integrin blockage and cytotoxic therapy, might also have a sensitising effect. In conjunction with radiotherapy, the most likely benefit to be derived from treatment with integrin inhibitors is an antiangiogenic effect. Indeed, administration of an $\alpha v \beta 3$ antibody/antagonist has been shown to result in the apoptosis of angiogenic but not of quiescent vascular cells (Brooks et al, 1994). And, functionblocking antibodies against $\alpha v \beta 3$ have been demonstrated to inhibit the VEGF-stimulated phosphorylation of VEGFR-2 and activation of the regulatory subunit of phosphatidyl isonitol 3-kinase (Soldi et al, 1999).

Several endogenous angiogenesis inhibitors may partially exert their antiproliferative effects via $\alpha v \beta 3$. This has been demonstrated for endostatin (Rehn et al, 2001), angiostatin (Tarui et al, 2001), thrombospondin-1 (for a review, see Bornstein, 2001) and tumstatin (Maeshima et al, 2000). Indeed, when molecules such as angiostatin (Gorski et al, 1998; Mauceri et al, 1998), endostatin (Hanna et al, 2000) or neutralising anti-human $\mathrm{VEGF}_{165}$ antibodies (Gorski et al, 1999; Lee et al, 2000) are administered together with ionising radiation, the cytotoxic effects of the latter upon endothelial cells are potentiated in vivo, resulting in an enhanced antitumoral effect. Likewise, when radiotherapy is combined with the administration either of antibodies against VEGFR-2 or of the antiangiogenic compound TNP-470, the growth-retarding effects of radiation is potentiated (Teicher et al, 1996; Lund et al, 2000; Hess et al, 2001; Kozin et al, 2001).

As far as we are aware, only one in vitro study has demonstrated a synergic, retarding effect of radiotherapy and $\alpha v \beta 3$ blockage on tumour cell growth (Abdollahi et al, 2003).

And as yet, there is no evidence indicating that a blockage of $\beta 3$-integrin expression results in radiosensitisation. Since integrinmediated cell signalling is implicated in cell migration, invasion and survival, targeting this event could be as important as the direct inhibition of angiogenesis.

In conclusion, there was a significant relationship between $\beta 3$-integrins expression and survival/local control in our heterogeneous group of patients with cervical cancer treated by radiotherapy. It seems worth investigating further the prognostic impact in a larger cohort of patients as it might have long-term implications in selecting patients who will do badly with standard treatment and might benefit from integrin modulation therapy.

\section{ACKNOWLEDGEMENTS}

We would like to thank $\mathrm{B}$ de Breuyn and $\mathrm{R}$ Buergy for their excellent technical assistance, the 'Bernese Radium-Foundation' for their support and the Swiss National Science Foundation (3100A0-104000/1) and the Bernese Cancer League for their continued support. 


\section{REFERENCES}

Abdollahi A, Zieher H, Roth A, Poerschke D, Debus J, Lipson K, Huber PE (2003) Enhancing radiation-induced inhibition of angiogenesis and tumor growth by an alpha-V-beta-3 integrin receptor antagonist. Int $J$ Radiat Oncol Biol Phys 57: S319-S320

Albelda SM, Mette SA, Elder DE, Stewart R, Damjanovich L, Herlyn M, Buck CA (1990) Integrin distribution in malignant melanoma: association of the beta 3 subunit with tumor progression. Cancer Res 50: 6757-6764

Bornstein P (2001) Thrombospondins as matricellular modulators of cell function. J Clin Invest 107: $929-934$

Brakebusch C, Bouvard D, Stanchi F, Sakai T, Fassler R (2002) Integrins in invasive growth. J Clin Invest 109: 999-1006

Brooks PC, Montgomery AM, Rosenfeld M, Reisfeld RA, Hu T, Klier G, Cheresh DA (1994) Integrin alpha $\mathrm{v}$ beta 3 antagonists promote tumor regression by inducing apoptosis of angiogenic blood vessels. Cell 79: 1157 - 1164

Burri P, Djonov V, Aebersold DM, Lindel K, Studer U, Altermatt HJ, Mazzucchelli L, Greiner RH, Gruber G (2003) Significant correlation of hypoxia-inducible factor-1alpha with treatment outcome in cervical cancer treated with radical radiotherapy. Int J Radiat Oncol Biol Phys 56: 494-501

Chattopadhyay N, Chatterjee A (2001) Studies on the expression of alpha(v)beta3 integrin receptors in non-malignant and malignant human cervical tumor tissues. J Exp Clin Cancer Res 20: 269-275

Chen YQ, Trikha M, Gao X, Bazaz R, Porter AT, Timar J, Honn KV (1997) Ectopic expression of platelet integrin alphaIIb beta3 in tumor cells from various species and histological origin. Int J Cancer 72: 642-648

Dedhar S (1999) Integrins and signal transduction. Curr Opin Hematol 6 $37-43$

Dedhar S, Hannigan GE (1996) Integrin cytoplasmic interactions and bidirectional transmembrane signalling. Curr Opin Cell Biol 8: 657-669

Eliceiri BP, Cheresh DA (2001) Adhesion events in angiogenesis. Curr Opin Cell Biol 13: $563-568$

Gasparini G, Brooks PC, Biganzoli E, Vermeulen PB, Bonoldi E, Dirix LY, Ranieri G, Miceli R, Cheresh DA (1998) Vascular integrin alpha(v) beta3: a new prognostic indicator in breast cancer. Clin Cancer Res 4: $2625-2634$

Gingras MC, Roussel E, Bruner JM, Branch CD, Moser RP (1995) Comparison of cell adhesion molecule expression between glioblastoma multiforme and autologous normal brain tissue. J Neuroimmunol 57: $143-153$

Gorski DH, Beckett MA, Jaskowiak NT, Calvin DP, Mauceri HJ, Salloum RM, Seetharam S, Koons A, Hari DM, Kufe DW, Weichselbaum RR (1999) Blockage of the vascular endothelial growth factor stress response increases the antitumor effects of ionizing radiation. Cancer Res 59: $3374-3378$

Gorski DH, Mauceri HJ, Salloum RM, Gately S, Hellman S, Beckett MA, Sukhatme VP, Soff GA, Kufe DW, Weichselbaum RR (1998) Potentiation of the antitumor effect of ionizing radiation by brief concomitant exposures to angiostatin. Cancer Res 58: 5686-5689

Hanna NN, Seetharam S, Mauceri HJ, Beckett MA, Jaskowiak NT, Salloum RM, Hari D, Dhanabal M, Ramchandran R, Kalluri R, Sukhatme VP, Kufe DW, Weichselbaum RR (2000) Antitumor interaction of short-course endostatin and ionizing radiation. Cancer J 6: 287-293

Hess C, Vuong V, Hegyi I, Riesterer O, Wood J, Fabbro D, Glanzmann C, Bodis S, Pruschy M (2001) Effect of VEGF receptor inhibitor PTK787/ ZK222584 (correction of ZK222548) combined with ionizing radiation on endothelial cells and tumour growth. Br J Cancer 85: 2010-2016

Hieken TJ, Farolan M, Ronan SG, Shilkaitis A, Wild L, Das Gupta TK (1996) Beta3 integrin expression in melanoma predicts subsequent metastasis. J Surg Res 63: 169-173

Hieken TJ, Ronan SG, Farolan M, Shilkaitis AL, Das Gupta TK (1999) Molecular prognostic markers in intermediate-thickness cutaneous malignant melanoma. Cancer 85: 375-382

Hodivala-Dilke KM, Reynolds AR, Reynolds LE (2003) Integrins in angiogenesis: multitalented molecules in a balancing act. Cell Tissue Res 314: $131-144$
Hynes RO (1992) Integrins: versatility, modulation, and signaling in cell adhesion. Cell 69: 11-25

Kawahara E, Ooi A, Nakanishi I (1995) Integrin distribution in gastric carcinoma: association of beta 3 and beta 5 integrins with tumor invasiveness. Pathol Int 45: 493-500

Kozin SV, Boucher Y, Hicklin DJ, Bohlen P, Jain RK, Suit HD (2001) Vascular endothelial growth factor receptor-2-blocking antibody potentiates radiation-induced long-term control of human tumor xenografts. Cancer Res 61: 39-44

Lee CG, Heijn M, di Tomaso E, Griffon-Etienne G, Ancukiewicz M, Koike C, Park KR, Ferrara N, Jain RK, Suit HD, Boucher Y (2000) Anti-vascular endothelial growth factor treatment augments tumor radiation response under normoxic or hypoxic conditions. Cancer Res 60: 5565-5570

Lund EL, Bastholm L, Kristjansen PE (2000) Therapeutic synergy of TNP470 and ionizing radiation: effects on tumor growth, vessel morphology, and angiogenesis in human glioblastoma multiforme xenografts. Clin Cancer Res 6: $971-978$

Maeshima Y, Colorado PC, Kalluri R (2000) Two RGD-independent alpha vbeta 3 integrin binding sites on tumstatin regulate distinct anti-tumor properties. J Biol Chem 275: 23745-23750

Mauceri HJ, Hanna NN, Beckett MA, Gorski DH, Staba MJ, Stellato KA, Bigelow K, Heimann R, Gately S, Dhanabal M, Soff GA, Sukhatme VP, Kufe DW, Weichselbaum RR (1998) Combined effects of angiostatin and ionizing radiation in antitumour therapy. Nature 394: 287-291

Miyamoto S, Teramoto H, Coso OA, Gutkind JS, Burbelo PD, Akiyama SK, Yamada KM (1995) Integrin function: molecular hierarchies of cytoskeletal and signaling molecules. J Cell Biol 131: $791-805$

Miyamoto S, Teramoto H, Gutkind JS, Yamada KM (1996) Integrins can collaborate with growth factors for phosphorylation of receptor tyrosine kinases and MAP kinase activation: roles of integrin aggregation and occupancy of receptors. J Cell Biol 135: 1633-1642

Pecheur I, Peyruchaud O, Serre CM, Guglielmi J, Voland C, Bourre F, Margue C, Cohen-Solal M, Buffet A, Kieffer N, Clezardin P (2002) Integrin alpha(v)beta3 expression confers on tumor cells a greater propensity to metastasize to bone. FASEB J 16: 1266-1268

Pignatelli M, Cardillo MR, Hanby A, Stamp GW (1992) Integrins and their accessory adhesion molecules in mammary carcinomas: loss of polarization in poorly differentiated tumors. Hum Pathol 23: 1159-1166

Rehn M, Veikkola T, Kukk-Valdre E, Nakamura H, Ilmonen M, Lombardo C, Pihlajaniemi T, Alitalo K, Vuori K (2001) Interaction of endostatin with integrins implicated in angiogenesis. Proc Natl Acad Sci USA 98: $1024-1029$

Shain KH, Landowski TH, Dalton WS (2000) The tumor microenvironment as a determinant of cancer cell survival: a possible mechanism for de novo drug resistance. Curr Opin Oncol 12: 557-563

Soldi R, Mitola S, Strasly M, Defilippi P, Tarone G, Bussolino F (1999) Role of alphavbeta3 integrin in the activation of vascular endothelial growth factor receptor-2. EMBO J 18: $882-892$

Stromblad S, Becker JC, Yebra M, Brooks PC, Cheresh DA (1996) Suppression of p53 activity and p21WAF1/CIP1 expression by vascular cell integrin alphaVbeta3 during angiogenesis. J Clin Invest 98: 426-433

Tarui T, Miles LA, Takada Y (2001) Specific interaction of angiostatin with integrin alpha(v)beta(3) in endothelial cells. J Biol Chem 276: $39562-$ 39568

Teicher BA, Holden SA, Ara G, Korbut T, Menon K (1996) Comparison of several antiangiogenic regimens alone and with cytotoxic therapies in the Lewis lung carcinoma. Cancer Chemother Pharmacol 38: 169-177

Trikha M, Timar J, Zacharek A, Nemeth JA, Cai Y, Dome B, Somlai B, Raso E, Ladanyi A, Honn KV (2002) Role for beta3 integrins in human melanoma growth and survival. Int J Cancer 101: 156-167

Varner JA, Cheresh DA (1996) Integrins and cancer. Curr Opin Cell Biol 8: $724-730$

Vonlaufen A, Wiedle G, Borisch B, Birrer S, Luder P, Imhof BA (2001) Integrin alpha(v)beta(3) expression in colon carcinoma correlates with survival. Mod Pathol 14: 1126-1132 